\title{
Meningkatkan Keterampilan Proses Sains dan Hasil Belajar Peserta Didik Menggunakan Model Pembelajaran Berbasis Masalah Dengan Berbantuan Media Simulasi Phet pada Materi Pokok Gelombang Mekanik Kelas XI MIA 3 SMAN 1 Mawasangka
}

\author{
Nurmin $^{1)}$ *, Muhammad Yuris ${ }^{2)}$, Luh Sukariasih ${ }^{3)}$ \\ 1)*Mahasiswa Jurusan Pendidikan Fisika Fakultas Keguruan dan Ilmu Pendidikan UHO \\ ${ }^{2), 3)}$ Dosen Jurusan Pendidikan Fisika Fakultas Keguruan dan Ilmu Pendidikan UHO \\ *Korespondensi Email: nurmin@gmail.com
}

\begin{abstract}
Abstrak: Penelitian ini bertujuan untuk meningkatkan: (1) keterampilan proses sains, (2) hasil belajar peserta didik kelas XI MIA3 SMAN 1 Mawasangka pada materi pokok Gelombang Mekanik yang diajar menggunakan model pembelajaran berbasis masalah dengan berbantuan media simulasi PhET. Jenis penelitian ini adalah Penelitian Tindakan Kelas (PTK) yang telah dilaksanakan dalam 2 (dua) siklus. Subjek dalam penelitian ini adalah peserta didik kelas XI MIA3 SMAN 1 Mawasangka berjumlah 29 orang yang terdaftar pada semester genap tahun ajaran 2018/2019. Instrumen penelitian terdiri atas lembar obeservasi keterampilan proses sains peserta didik dan aktivitas guru serta tes hasil belajar. Data penelitian dianalisis secara statistik deskriptif. Dari hasil analisis data diperoleh nilai rata-rata aspek keterampilan proses sains peserta didik pada siklus I yaitu 1,9 dengan kategori cukup, sedangkan untuk nilai rata-rata hasil belajar peserta didik pada siklus I yaitu 86,03. Untuk ketuntasan belajar secara klasikal peserta didik pada siklus I yaitu dengan persentase keberhasilan tindakan sebesar 79,3\%. Pada siklus II nilai rata-rata aspek keterampilan proses sains peserta didik yaitu 2,7 dengan kategori baik. Untuk nilai rata-rata hasil belajar peserta didik pada siklus II diperoleh 87,93. Pada siklus II ketuntasan belajar peserta didik secara klasikal yaitu dengan persentase keberhasilan tindakan sebesar 86,2\%. Berdasarkan hasil penelitian dan pembahasan dapat disimpulkan bahwa pembelajaran Fisika pada materi pokok Gelombang Mekanik yang diajar menggunakan model pembelajaran berbasis masalah dengan berbantuan media simulasi PhET mengalami peningkatan pada keterampilan proses sains, hasil belajar peserta didik kelas XI MIA3 SMAN 1 Mawasangka dari siklus I ke siklus II.
\end{abstract}

Kata Kunci: Pembelajaran berbasis masalah, simulasi PhET, aktivitas mengajar, keterampilan proses sains, hasil belajar

\begin{abstract}
This study aims to improve: (1) science process skills, (2) student learning outcomes in class XI MIA3 SMAN 1 Mawasangka on the subject matter of Mechanical Waves taught using problem-based learning models with the help of PhET simulation media. This type of research is Classroom Action Research $(C A R)$ which has been carried out in 2 (two) cycles. The subjects in this study were students of class XI MIA3 of SMAN 1 Mawasangka with 29 people enrolled in the even semester of the 2018/2019 school year. The research instrument consisted of observing sheets of students' science process skills and teacher activities as well as learning achievement tests. The research data were analyzed using descriptive statistics. From the results of data analysis, the average value of aspects of the science process skills of students in the first cycle is 1.9 with enough categories, while for the average value of the learning outcomes of students in the first cycle is 86.03. For classical mastery learning students in the first cycle is the percentage of successful actions of 79.3\%. In cycle II the average value of aspects of the science process skills of students is 2.7 with a good category. For the average value of student learning outcomes in the second cycle obtained 87.93. In the second cycle of student learning completeness in a classical manner with a percentage of $86.2 \%$ success of the action. Based on the results of research and discussion it can be concluded that Physics learning on the subject matter of Mechanical Waves taught using problem-based learning models assisted by PhET simulation media has increased in science process skills, the learning outcomes of class XI MIA3 students of SMAN 1 Mawasangka from cycle I to cycle II
\end{abstract}

Keywords: Problem based learning, PhET simulation, teaching activities, science process skills, learning outcomes. 
Jurnal Penelitian Pendidikan Fisika, Vol. 4 No. 3 Juli 2019, 164-173

\section{PENDAHULUAN}

Pendidikan adalah salah satu bentuk perwujudan kebudayaan manusia yang dinamis dan syarat perkembangan. Kegiatan belajar mengajar merupakan suatu kegiatan yang paling pokok, hal ini berarti keberhasilan atau tidaknya sistem pendidikan sangat tergantung pada proses pembelajaran. Pembelajaran merupakan proses kerja sama dan komunikasi antara peserta didik dengan guru atau dengan lingkungannya untuk mencapai suatu tujuan tertentu, salah satu pembelajaran yang terdapat di sekolah adalah pelajaran yang mempelajari tentang peristiwa alam yaitu fisika (Wardhani, 2012).

Fisika merupakan cabang ilmu pengetahuan yang mempelajari berbagai peristiwa alam, meliputi segala akibat dan dampak terhadap kehidupan. Ilmu tersebut selalu berkembang seiring dengan kemajuan ilmu pengetahuan dan teknologi. Untuk itulah, perlu penyampaian peristiwa-peristiwa dalam kehidupan guna meningkatkan pemahaman konsep fisika secara menarik dengan berbasis teknologi.

Namun pada kenyataannya, pelajaran fisika ini termasuk pelajaran yang banyak ditakuti dan kurang diminati oleh para peserta didik karena mata pelajaran ini dianggap sulit. Seharusnya pembelajaran di sekolah membuat peserta didik mengembangkan potensi yang dimiliki. Dengan melihat keadaan itu, guru diharapkan dapat menciptakan suasana pembelajaran yang dapat memotivasi peserta didik dalam mengikuti pembelajaran fisika serta dapat meningkatkan keterampilan proses sains.

Berdasarkan hasil observasi dan wawancara yang telah dilakukan terhadap aktivitas mengajar guru mata pelajaran fisika dan aktivitas belajar peserta didik kelas XI MIA3 di SMAN 1 Mawasangka dengan jumlah peserta didik 29 orang yang terdiri dari 11 orang lakilaki dan 18 orang perempuan diperoleh gambaran rendahnya aktivitas peserta didik serta rendahnya keterampilan proses sains, dimana guru yang masih mendominasi proses pembelajaran dan peserta didik hanya duduk menerima penjelasan yang diberikan oleh guru sehingga mereka tidak terpacu untuk berpikir kritis.

Selain itu diperoleh gambaran rendahnya hasil belajar peserta didik pada semester ganjil tahun ajaran 2018/2019, dimana nilai yang diperoleh peserta didik pada mata pelajaran fisika di kelas XI MIA3 SMAN 1 Mawasangka cukup rendah. Dari nilai KKM sekolah untuk mata pelajaran fisika yaitu 73 (Kurikulum 2013), hasil belajar peserta didik yang terdiri dari 29 orang peserta didik, yang memperoleh nilai $\leq 73$ hanya 10 orang peserta didik atau $34,48 \%$, sedangkan peserta didik yang memperoleh nilai $\geq 73$ sebanyak 19 orang peserta didik atau $65,52 \%$. Nilai tersebut tentunya perlu perhatian dari berbagai pihak khususnya guru mata pelajaran fisika untuk melakukan alternatif baru dalam rangka perbaikan proses belajar mengajar untuk meningkatkan hasil belajar peserta didik.

Adapun penyebab permasalahan yang dialami oleh peserta didik dalam pembelajaran tersebut, yaitu guru masih menggunakan model pembelajaran yang banyak berpusat pada guru sehingga peserta didik menjadi pasif karena peserta didik hanya duduk menerima penjelasan dari guru. Hal ini menyebabkan peserta didik cenderung cepat merasa bosan dan sulit untuk memahami materi pembelajaran yang diberikan oleh guru. Sehingga pada waktu guru sedang menjelaskan materi pembelajaran, peserta didik ada yang membuat kesibukan sendiri, seperti bermain, menggambar serta cerita-cerita dengan teman sebangkunya. Sehingga untuk menanggulangi hal tersebut, maka guru harus memilih model pembelajaran yang sesuai dengan karakteristik peserta didik maupun materi yang diajarkan. Salah satu model pembelajaran yang menekankan pada usaha untuk mememecahkan masalah dan meningkatan keteranpilan proses sains peserta didik yang membuat para peserta didik terlihat lebih aktif adalah dengan menggunakan model pembelajaran berbasis masalah (Problem Based Learning). Selain model pembelajaran tersebut perlu pula digunakan media pembelajara untuk memotivasi peserta didik dalam mengikuti proses pembelajaran. Seiring dengan perkembangan teknologi informasi sekarang ini, para ahli berupaya mengembangkan berbagai media pembelajaran berbasis komputer.

Salah satu bentuk media pembelajaran adalah media laboratorium virtual. Lilis dalam Eko Sumargo dan Leny Yuanita (2014) mendefinisikan bahwa laboratorium virtual atau PhET adalah suatu bentuk laboratorium dengan kegiatan pengamatan atau eksperimen dengan menggunakan software yang dijalankan oleh sebuah komputer, semua peralatan yang diperlukan laboratorium virtual atau PhET memiliki beberapa keunggulan. Keunggulan-keunggulan itu antara lain adalah bisa menjelaskan konsep abstrak yang tidak bisa dijelaskan melalui penyampaian secara verbal. Laboratorium virtual bisa menjadi tempat melakukan eksperimen yang tidak bisa dilakukan di dalam laboratorium konvensional.

Menurut Mustafa \& Trudel dalam Zainudin (2017) Pembelajaran menggunakan PhET sebagai laboratorium virtual PhET memberi kesempatan peserta didik melakukan eksperimen mengidentifikasi dan 
mengembangkan hubungan variabel eksperimen, peserta didik bebas bekerja memanipulasi variabel objek eksperimen dan aman dalam melakukan aktivitas.

Berdasarkan uraian di atas dapat dikatakan bahwa, pendekatan pembelajaran berbasis masalah (Problem Based Learning) dengan berbantuan media simulasi PhET kemungkinan dapat meningkatkan keterampilan proses sains dan hasil belajar peserta didik pada materi Gelombang Mekanik, karena dengan model pembelajaran berbasis masalah tersebut peserta didik akan terlihat aktif dalam memperoleh pengetahuan dan penggunaan media simulasi PhET pada proses pembelajaran dapat menarik perhatian peserta didik sehingga dalam proses pembelajaran tidak berlangsung membosankan. Maka untuk membahas dan mengangkat permasalahan ini akan dilakukan penelitian yang berjudul Meningkatkan Keterampilan Proses Sains dan Hasil Belajar Peserta Didik Menggunakan Model Pembelajaran Berbasis Masalah dengan Berbantuan Simulasi PhET pada Materi Pokok Gelombang Mekanik Kelas XI MIA3 SMAN 1 Mawasangka.

\section{METODE}

Penelitian ini telah dilaksanakan pada semester genap tahun ajaran 2018/2019 di kelas XI MIA 3 SMAN 1 Mawasangka pada materi pokok Gelombang Mekanik, dengan jenis penelitian adalah Penelitian Tindakan Kelas (PTK). Rancangan siklus penelitian tindakan kelas yang dilakukan adalah sebagai berikut:

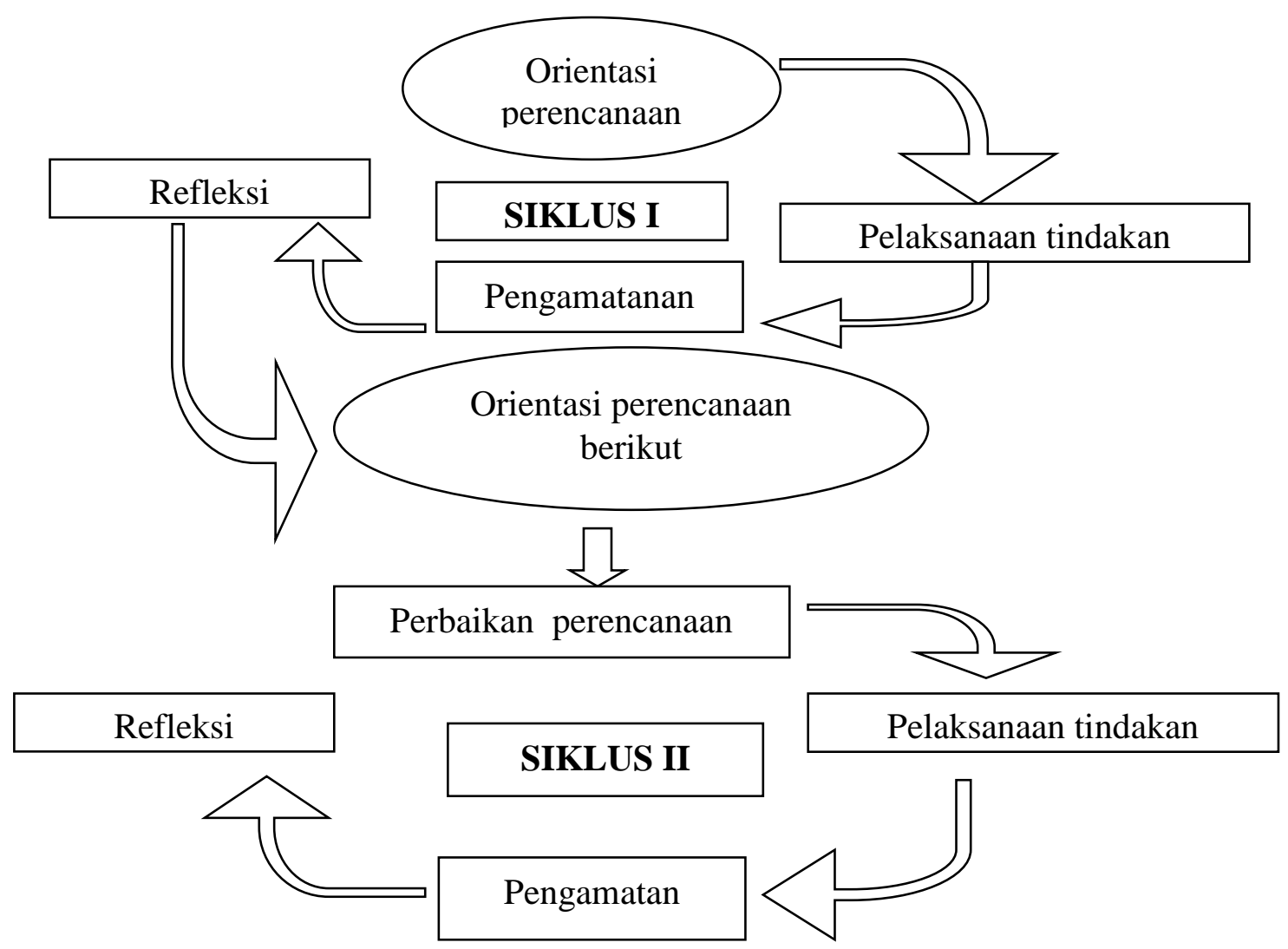

Gambar 1 Desain penelitian tindakan kelas (Iskandar, 2012: 67).

Teknik analisis data yang digunakan berupa analisis deskriptif yang dimaksudkan untuk memberikan gambaran optimalisasi penerapan model pembelajaran berbasis masalah dengan berbantuan simulasi PhET yang terlihat dari besar peningkatan hasil belajar dan keterampilan proses sains peserta didik pada materi pokok gelombang mekanik. Pengklasifikasikan rata-rata skor aktivitas guru, dengan mengikuti aturan pengkategorian sebagai berikut.

$1 \leq$ rata-rata $<1,75 \quad=$ Aktivitas guru kurang

$1,75 \leq$ rata-rata $<2,5=$ Aktivitas guru cukup

$2,5 \leq$ rata-rata $<3,25=$ Aktivitas guru baik

$3,25 \leq$ rata-rata $<4=$ Aktivitas guru sangat baik 
Pengklasifikasi nilai hasil belajar peserta didik mengikuti aturan pengkategorian sebagai berikut.
$80-100$
: Sangat tinggi
$66-79$
: Tinggi
$56-65$
: Sedang
$46-55$
: Rendah
$0-45$
: Sangat rendah

HASIL PENELITIAN

Keterampilan Proses Sains Peserta Didik

Tabel 1. Rata-rata keterampilan proses sains kelompok peserta didik setiap pertemuan pada siklus I

\begin{tabular}{|c|c|c|c|c|c|c|c|c|c|c|c|c|c|c|}
\hline \multirow{5}{*}{ No } & \multirow{5}{*}{$\begin{array}{c}\text { Aspek-aspek yang } \\
\text { diamati }\end{array}$} & \multicolumn{13}{|c|}{ SIKLUS I } \\
\hline & & \multirow{2}{*}{\multicolumn{6}{|c|}{$\begin{array}{c}\text { Pertemuan } 1 \\
\text { LKPD } 01\end{array}$}} & \multicolumn{6}{|c|}{ Pertemuan 2} & \multirow{4}{*}{ Rata-rata } \\
\hline & & & & & & & & \multicolumn{6}{|c|}{ LKPD 02} & \\
\hline & & \multicolumn{5}{|c|}{ Kelompok } & \multirow{2}{*}{$\mathbf{R}$} & \multicolumn{5}{|c|}{ Kelompok } & \multirow{2}{*}{$\mathbf{R}$} & \\
\hline & & $\mathbf{I}$ & II & III & IV & $\mathbf{V}$ & & $\mathbf{I}$ & II & III & IV & $\mathbf{V}$ & & \\
\hline 1 & $\begin{array}{l}\text { Observasi } \\
\text { (Mengamati) }\end{array}$ & 2 & 2 & 2 & 1 & 1 & 1.6 & 3 & 2 & 3 & 2 & 3 & 2.6 & 2.1 \\
\hline 2 & $\begin{array}{l}\text { Merumuskan } \\
\text { Masalah/Hipotesis }\end{array}$ & 1 & 1 & 1 & 1 & 1 & 1 & 2 & 2 & 2 & 3 & 2 & 2.2 & 1.6 \\
\hline 3 & Melakukan percobaan & 2 & 2 & 2 & 2 & 2 & 2 & 2 & 3 & 2 & 3 & 2 & 2.4 & 2.2 \\
\hline 4 & $\begin{array}{l}\text { Menafsirkan } \\
\text { pengamatan }\end{array}$ & 1 & 2 & 1 & 1 & 2 & 1.4 & 2 & 3 & 2 & 2 & 3 & 2.4 & 1.9 \\
\hline 5 & $\begin{array}{l}\text { Menerapkan Konsep } \\
\text { dan Prinsip }\end{array}$ & 2 & 2 & 2 & 2 & 2 & 2 & 2 & 2 & 2 & 2 & 3 & 2.2 & 2.1 \\
\hline 6 & Menyimpulkan & 1 & 2 & 1 & 2 & 1 & 1.4 & 3 & 2 & 3 & 2 & 2 & 2.4 & 1.9 \\
\hline 7 & Mengkomunikasikan & 2 & 1 & 2 & 2 & 2 & 1.8 & 2 & 2 & 2 & 2 & 3 & 2.2 & 2 \\
\hline \multicolumn{2}{|c|}{ Jumlah } & 11 & 12 & 11 & 11 & 11 & 11.2 & 16 & 16 & 16 & 16 & 18 & 16 & 13.8 \\
\hline \multicolumn{2}{|c|}{ Rata-rata Skor } & & & & & & & & & & & & & 1.9714 \\
\hline \multicolumn{2}{|c|}{ Kategori } & & & & & & & & & & & & & Cukup \\
\hline
\end{tabular}

Tabel 2. Rata-rata keterampilan proses sains peserta didik setiap pertemuan pada siklus II

\section{SIKLUS II}

\begin{tabular}{|c|c|c|c|c|c|c|c|c|}
\hline \multirow{4}{*}{ No } & \multirow{4}{*}{ Aspek-aspek yang diamati } & \multicolumn{7}{|c|}{ Pertemuan 3} \\
\hline & & \multicolumn{7}{|c|}{ LKPD 01} \\
\hline & & \multicolumn{5}{|c|}{ Kelompok } & \multirow[t]{2}{*}{$\begin{array}{c}\text { Rata- } \\
\text { rata }\end{array}$} & \multirow[t]{2}{*}{ Kategori } \\
\hline & & $\mathbf{I}$ & II & III & IV & $\mathbf{V}$ & & \\
\hline 1 & Observasi (Mengamati) & 3 & 3 & 3 & 2 & 3 & 2.8 & Baik \\
\hline 2 & Merumuskan Masalah/Hipotesis & 3 & 2 & 2 & 3 & 3 & 2.6 & Baik \\
\hline 3 & Melakukan percobaan & 3 & 3 & 3 & 3 & 3 & 3 & Baik \\
\hline 4 & Menafsirkan pengamatan & 3 & 3 & 3 & 3 & 3 & 3 & Baik \\
\hline 5 & Menerapkan Konsep dan Prinsip & 2 & 3 & 3 & 2 & 3 & 2.6 & Baik \\
\hline 6 & Menyimpulkan & 3 & 2 & 3 & 3 & 2 & 2.6 & Baik \\
\hline 7 & Mengkomunikasikan & 3 & 3 & 2 & 2 & 3 & 2.6 & Baik \\
\hline \multicolumn{2}{|c|}{ Jumlah } & 20 & 19 & 19 & 18 & 20 & \multicolumn{2}{|c|}{19.2} \\
\hline \multicolumn{2}{|c|}{ Rata-rata Skor } & & & & & & \multirow{2}{*}{\multicolumn{2}{|c|}{.74286}} \\
\hline \multicolumn{2}{|c|}{ Kategori } & & & & & & & \\
\hline
\end{tabular}




\section{Aktivitas Guru}

Tabel 3. Data Skor Rata-rata Aktivitas Guru pada Setiap Siklus

\begin{tabular}{|c|c|c|c|c|c|}
\hline \multirow{2}{*}{$\begin{array}{l}\text { No } \\
\text { I } \\
\end{array}$} & \multirow{2}{*}{$\begin{array}{c}\text { Aktivitas yang Diamati } \\
\text { A. Pendahuluan } \\
\end{array}$} & \multicolumn{4}{|c|}{ Skor Aktivitas } \\
\hline & & & \multirow{2}{*}{$\begin{array}{c}\text { Kategori } \\
\text { SB }\end{array}$} & \multirow{2}{*}{$\begin{array}{c}\text { SIKLUS II } \\
4\end{array}$} & \multirow{2}{*}{$\begin{array}{c}\text { Kategori } \\
\text { SB }\end{array}$} \\
\hline & $\begin{array}{l}\text { 1.Guru mengucapkan salam pembuka, } \\
\text { berdoa dan memeriksa kehadiran peserta } \\
\text { didik }\end{array}$ & 4 & & & \\
\hline & $\begin{array}{l}\text { 2.Guru menyiapkan fisik dan psikis } \\
\text { peserta didik dalam mengawali kegiatan } \\
\text { pembelajaran }\end{array}$ & 3 & B & 4 & SB \\
\hline & $\begin{array}{l}\text { 3.Guru memberikan apersepsi } \text { dan } \\
\text { motivasi kepada peserta didik }\end{array}$ & 3 & B & 4 & SB \\
\hline & $\begin{array}{ll}\text { 4.Guru menyampaikan } & \text { tujuan } \\
\text { pembelajaran } & \end{array}$ & 3 & B & 4 & SB \\
\hline \multirow[t]{8}{*}{ II } & B. Kegiatan Inti & & & & \\
\hline & $\begin{array}{l}\text { 5.Guru membagi peserta didik dalam } \\
\text { beberapa kelompok belajar }\end{array}$ & 4 & SB & 4 & SB \\
\hline & $\begin{array}{l}\text { 6.Guru memberikan stimulus atau } \\
\text { rangsangan }\end{array}$ & 3 & B & 4 & SB \\
\hline & $\begin{array}{l}\text { 7.Guru membagikan LKPD } \text { dan } \\
\text { menjelaskan tentang tugas yang akan } \\
\text { dikerjakan }\end{array}$ & 4 & SB & 4 & SB \\
\hline & $\begin{array}{l}\text { 8.Guru membimbing } \\
\text { melakukan percobaan } \\
\text { data dan infongumpulkan } \\
\text { petunjuk dalam LKPD }\end{array}$ & 4 & SB & 4 & SB \\
\hline & $\begin{array}{l}\text { 9.Guru membimbing peserta } \\
\text { melakukan didik } \\
\text { percobaan yang telah dilakukan }\end{array}$ & 3 & B & 3 & B \\
\hline & $\begin{array}{l}\text { 10.Guru meminta perwakilan peserta } \\
\text { didik dalam setiap kelompok untuk } \\
\text { mempresentasikan hasil percobaan dan } \\
\text { diskusinya }\end{array}$ & 3.5 & SB & 4 & B \\
\hline & $\begin{array}{l}\text { 11.Guru memberika kesimpulan dari hasil } \\
\text { percobaan yang telah dilakukan peserta } \\
\text { didik }\end{array}$ & 3 & B & 4 & SB \\
\hline \multirow[t]{3}{*}{ III } & C. Kegiatan akhir & & & & \\
\hline & $\begin{array}{l}\text { 12.Guru bersama peserta didik meriview } \\
\text { dan menyimpulkan materi yang telah } \\
\text { dipelajari }\end{array}$ & 3.5 & SB & 4 & SB \\
\hline & $\begin{array}{l}\text { 13. Guru menyampaikan materi } \\
\text { selanjutnya dan mengucapkan salam }\end{array}$ & 4 & SB & 4 & SB \\
\hline \multirow[t]{3}{*}{ IV } & D. Suasana Kelas & & & & \\
\hline & 14.Peserta didik antusias & 3.5 & SB & 4 & SB \\
\hline & 15.Guru antusias & 3.5 & SB & 4 & SB \\
\hline
\end{tabular}




\begin{tabular}{lcccc}
\hline 16.Waktu sesuai alokasi & 2.5 & B & 3 & B \\
\cline { 2 - 4 } 17.KBM sesuai dengan RPP & 3 & B & 3 & B \\
\hline Jumlah & 57.5 & 65 \\
\hline Skor Rata-rata & 3.382352941 & 3.823529412 \\
\hline Kategori & SB & SB \\
\hline
\end{tabular}

\section{Hasil Belajar Peserta Didik}

Tabel 4 Data Analisis Nilai Hasil Belajar Peserta Didik

\begin{tabular}{|c|c|c|c|c|c|}
\hline \multirow{2}{*}{ NO } & \multirow{2}{*}{ NAMA } & \multicolumn{2}{|c|}{ SIKLUS I } & \multicolumn{2}{|c|}{ SIKLUS II } \\
\hline & & NILAI & KETERANGAN & NILAI & KETERANGAN \\
\hline 1 & AHM & 90 & $\mathrm{~T}$ & 90 & $\mathrm{~T}$ \\
\hline 2 & ASTR & 85 & $\mathrm{~T}$ & 90 & $\mathrm{~T}$ \\
\hline 3 & FAZ & 70 & $\mathrm{BT}$ & 90 & $\mathrm{~T}$ \\
\hline 4 & FIT & 85 & $\mathrm{~T}$ & 80 & $\mathrm{~T}$ \\
\hline 5 & IS & 65 & BT & 70 & BT \\
\hline 6 & ISM & 85 & $\mathrm{~T}$ & 100 & $\mathrm{~T}$ \\
\hline 7 & ISN & 100 & $\mathrm{~T}$ & 90 & $\mathrm{~T}$ \\
\hline 8 & L.M. D & 85 & $\mathrm{~T}$ & 95 & $\mathrm{~T}$ \\
\hline 9 & LA O & 80 & $\mathrm{~T}$ & 95 & $\mathrm{~T}$ \\
\hline 10 & LEN & 70 & BT & 80 & $\mathrm{~T}$ \\
\hline 11 & LUF & 90 & $\mathrm{~T}$ & 95 & $\mathrm{~T}$ \\
\hline 12 & MIL & 100 & $\mathrm{~T}$ & 95 & $\mathrm{~T}$ \\
\hline 13 & MUH. AB & 100 & $\mathrm{~T}$ & 100 & $\mathrm{~T}$ \\
\hline 14 & MUH. AL & 90 & $\mathrm{~T}$ & 95 & $\mathrm{~T}$ \\
\hline 15 & MUH. AM & 85 & $\mathrm{~T}$ & 95 & $\mathrm{~T}$ \\
\hline 16 & NAS & 100 & $\mathrm{~T}$ & 60 & $\mathrm{BT}$ \\
\hline 17 & NUR & 90 & $\mathrm{~T}$ & 100 & $\mathrm{~T}$ \\
\hline 18 & NUR F & 90 & $\mathrm{~T}$ & 100 & $\mathrm{~T}$ \\
\hline 19 & NUR H & 100 & $\mathrm{~T}$ & 100 & $\mathrm{~T}$ \\
\hline 20 & NURHI & 100 & $\mathrm{~T}$ & 60 & BT \\
\hline 21 & RAH & 90 & $\mathrm{~T}$ & 85 & $\mathrm{~T}$ \\
\hline 22 & $\mathrm{SAH}$ & 70 & $\mathrm{BT}$ & 75 & $\mathrm{~T}$ \\
\hline 23 & SIT & 75 & $\mathrm{~T}$ & 95 & $\mathrm{~T}$ \\
\hline 24 & WDA & 90 & $\mathrm{~T}$ & 100 & $\mathrm{~T}$ \\
\hline 25 & WDM & 55 & $\mathrm{BT}$ & 75 & $\mathrm{~T}$ \\
\hline 26 & WDMA & 65 & $\mathrm{BT}$ & 75 & $\mathrm{~T}$ \\
\hline 27 & WDR & 95 & $\mathrm{~T}$ & 100 & $\mathrm{~T}$ \\
\hline 28 & WIW & 95 & $\mathrm{~T}$ & 100 & $\mathrm{~T}$ \\
\hline 29 & $\mathrm{ZU}$ & 100 & $\mathrm{~T}$ & 65 & $\mathrm{BT}$ \\
\hline \multicolumn{2}{|c|}{ Jumlah } & \multicolumn{2}{|r|}{2495} & \multicolumn{2}{|r|}{2550} \\
\hline \multicolumn{2}{|c|}{ Nilai Rat-rata } & \multicolumn{2}{|r|}{86,0} & \multicolumn{2}{|r|}{87,9} \\
\hline \multicolumn{2}{|c|}{ Nilai Maksimum } & \multicolumn{2}{|r|}{100} & \multicolumn{2}{|r|}{100} \\
\hline \multicolumn{2}{|c|}{ Nilai Minimum } & \multicolumn{2}{|r|}{55} & \multicolumn{2}{|r|}{60} \\
\hline \multicolumn{2}{|c|}{ Standar Deviasi } & \multicolumn{2}{|c|}{12,4197} & \multicolumn{2}{|r|}{12,7837} \\
\hline
\end{tabular}




\begin{tabular}{lcc}
\hline Jumlah T & 23 & 25 \\
\hline Jumlah BT & 6 & 4 \\
\hline \% Tuntas & $\mathbf{7 9 , 3 \%}$ & $\mathbf{8 6 , 2 \%}$ \\
\hline \% Belum Tuntas & $\mathbf{2 0 , 7 \%}$ & $\mathbf{1 3 , 8 \%}$ \\
\hline
\end{tabular}

Tabel 5. Data Ketuntasan Belajar Peserta Didik Siklus I dan Siklus II

\begin{tabular}{cccccc}
\hline \multirow{2}{*}{ No } & \multirow{2}{*}{ Jenis } & \multicolumn{3}{c}{ Ketuntasan } \\
\cline { 3 - 6 } & Evaluasi & \multicolumn{2}{c}{ Tuntas } & \multicolumn{2}{c}{ Belum Tuntas } \\
\cline { 3 - 6 } & & Frekuensi (orang) & Persentase (\%) & Frekuensi (orang) & Persentase (\%) \\
\hline 1. & Siklus I & 23 & $79,3 \%$ & 6 & $20,7 \%$ \\
\hline 2. & Siklus II & 25 & $86,2 \%$ & 4 & $13,8 \%$ \\
\hline
\end{tabular}

\section{Pembahasan}

Pelaksanaan penelitian tindakan kelas (PTK) dengan menggunakan model pembelajaran berbasis masalah dengan berbantuan simulasi PhET, terdiri dari 2 siklus, dimana siklus I terdiri dari 2 kali pertemuan dan siklus II terdiri dari 1 kali pertemuan. Subjek dalam penelitian ini adalah peserta didik kelas XI MIA 3 SMAN 1 Mawasangka berjumlah 29 peserta didik yang terdiri dari 11 peserta didik laki-laki dan 18 peserta didik perempuan.

Data yang dikumpulkan dalam penelitian ini adalah keterampilan proses sains peserta didik yang diperoleh melalui lembar observasi dan hasil belajar peserta didik dengan materi pokok gerak parabola yang diperoleh melalui tes hasil belajar. Data yang diperoleh kemudian dianalisis dan disajikan dengan metode yang telah ditetapkan sebelumnya.

\section{Siklus I}

Siklus I dilaksanakan sesuai rencana yaitu dua kali pertemuan pada tanggal 30 Maret - 9 April 2019. Pada pertemuan pertama yang dipelajari adalah sub materi pokok gelombang mekanik dan jenis-jenisnya dan pertemuan kedua adalah sub materi pokok gejala gelombang (pemantulan dan pembiasan).

\section{Keterampilan Proses sains Peserta Didik}

Berdasarkan hasil analisis deskriptif pada aspekaspek keterampilan proses sains peserta didik pada siklus I menunjukkan bahwa rata-rata keterampilan proses sains peserta didik sebesar 1,9 dengan kategori cukup. Dari 7 aspek keterampilan proses sains yang diamati terdapat 3 aspek yang berada dalam kategori kurang yaitu merumuskan masalah/hipotesis dengan skor 1 dan menafsirkan percobaan serta menyimpulkan skor rata-rata yang diperoleh sama yaitu 1,4. Sedangkan 4 aspek lainnya berada dalam kategori cukup yaitu observasi(mengamati), melakukan percobaan, menerapkan konsep dan prinsip, dan mengkomunikasikan dengan masing-masing skor ratarata yaitu 1,6,2, 2 dan 1,8. Masih terdapatnya beberapa aspek keterampilan proses sains yang tergolong rendah dikarenakan peserta didik belum terbiasa dengan model pembelajaran berbasis masalah yang diterapkan serta penggunaan simulasi PhET yangmerupakan hal baru bagi mereka. Selain itu peserta didik juga tidak terbiasa mengerjakan Lembar Kerja Peserta Didik (LKPD) dimana terdapat kegiatan merumuskan masalah/hipotesis, melaksanakan percobaan dan beberapa aspek keterampilan proses sains lainnya. Solusi yang diupayakan yaitu guru harus lebih berusaha dalam membimbing peserta didik saat proses pembelajaran, mendekatkan diri kepada peserta dituntut selalu bertukar informasi dan menanyakan masalah apa yang menjadi kendala pada saat pembelajaran berlangsung.

\section{Aktivitas Guru}

Berdasarkan hasil analisis terhadap aktivitas guru pada siklus I yaitu untuk pertemuan pertama diperoleh skor rata-rata sebesar 3,2 dengan kategori sangat baik dan pada pertemuan kedua diperoleh skor rata-rata sebesar 3,5 dengan kategori sangat baik pula. Dimana terdapat beberapa aspek aktivitas guru yang masih berada pada kategori cukup pada pertemuan pertama. Aspek aktivitas guru yang berada pada kategori cukup adalah waktu, dimana waktu pelaksanaan pembelajaran tidak sesuai alokasi waktu yang telah ditentukan. Namun untuk skor rata-ratanya pada siklus I sudah sangat baik. Dan untuk aktivitas guru pada pertemuan ketiga tepatnya siklus II sudah lebih baik lagi dari siklus I, dimana diperoleh skor rata-rata sebesar 3,8 dengan kategori sangat baik pula. Dan untuk alokasi waktu masih belum sesuai, namun sudah agak meningkat dengan kategori baik.

Belum maksimalnya aktivitas mengajar disebabkan guru belum sepenuhnya menguasai pembelajaran sesuai 
dengan langkah-langkah model pembelajaran berbasis masalah sehingga masih terdapat beberapa kekurangan dalam pelaksanaannya.

\section{Hasil Belajar}

Hasil belajar merupakan kemampuan yang dicapai peserta didik setelah mengikuti proses pembelajaran. Hasil belajar pengetahuan peserta didik diperoleh dari nilai tes hasil belajar yang diberikan guru kepada peserta didik melalui proses pembelajaran dengan menggunakan model pembelajaran berbasis masalah dengan berbantuan siimulasi PhET. Tes hasil belajar pengetahuan dilakukan setiap akhir siklus, dimana setiap siklus diberikan tes uraian yang berjumlah 5 butir soal. Kurangnya hasil belajar yang diperoleh peserta didik pada siklus I terlihat dari data analisis hasil belajar peserta didik yang menunjukkan perolehan nilai minimum sebesar 55, nilai maksimum sebesar 100, dan rata-rata hasil belajar peserta didik sebesar 86,3. Jika diklasifikasikan masih terdapat 6 peserta didik yang memperoleh nilai hasil belum tuntas atau cukup rendah. Selebihnya memperoleh nilai tinggi.

Dari data nilai hasil belajar peserta didik menunjukkan persentase ketuntasan belajar yang diperoleh pada siklus I telah mencapai target penelitian yaitu mencapai ketuntasan belajar secara klasikal $75 \%$. Jumlah persentase ketuntasan belajar pada siklus I yang diperoleh secara klasikal yaitu 79,3\% atau 23 peserta didik yang telah mencapai KKM yang ditentukan oleh sekolah yaitu $\geq 73$.

Berdasarkan hasil analisis deskriptif terhadap banyaknya persentase pesera didik yang belum mencapai standar KKM menunjukan adanya beberapa kekurangan dalam proses pembelejaran siklus I, diantaranya peserta didik yang belum terbiasa dengan model pembelajaran berbasis masalah, peserta didik juga belum terbiasa dalam menggunakan media PhET, serta peserta didik yang masih kurang dalam memahami soal tes hasil belajar serta guru yang belum optimal membimbing dan mengarahkan peserta didik dalam proses pembelajaran terutama ketika peserta didik melakukan percobaan melalui simulasi PhET.

\section{Refleksi}

Dari masalah tersebut peneliti dan guru mata pelajaran melakukan analisis dan refleksi terhadap faktor-faktor yang menyebabkan kurangnya keterampilan proses sains peserta didik dan beberapa aspek aktivitas guru dalam proses pembelajaran, antara lain: 1) Dimana peserta didik masih belum paham dalam penggunaan media PhET. 2) Peserta didik belum memahami bagaimana merumuskan masalah/hipotesis. 3) Peserta didik belum memahami bagaimana menafsirkan dan penyimpulan pengamatan. 4) Serta waktu yang belum sesui dengan alokasi waktu yang telah ditentukan.

Selanjutnya peneliti bersama guru juga menentukan langkah-langkah perbaikan untuk siklus II, yaitu: 1) Guru perlu menjelaskan lebih rinci lagi dan lebih dibimbing dalam melakukan percobaan menggunakan simulasi PhET. 2) Guru yang harus lebih menjelaskan lagi dan memberi contoh bagaimana merumuskan masalah / hipotesis, menafsirkan pengamatan dan menyimpulkan sesuatu itu dengan baik dan benar. 3) Serta waktu pembelajarannya perlu diperbaiki lagi agar sesuai dengan alokasi waktu yang telah ditentukan dalam RPP.

\section{Siklus II}

Siklus II dilaksanakan 1 kali pertemuan, yaitu pada tanggal 13 April 2019. Pada siklus ini proses pembelajaran berlangsung berdasarkan RPP yang telah ditetapkan dengan sub materi pokok gejala gelombang (difraksi dan interferensi).

\section{Keterampilan proses sains}

Bersdasarkan hasil analisis deskriptif pada siklus II menunjukkan adanya peningkatan keterampilanp proses sains peserta didik dari siklus I. Aspek-aspek keterampilan proses sains yang pada siklus I berada pada kategori kurang dan cukup mengalami peningkatan yang lebih baik dengan perolehan skor rata-rata keterampilan proses sains sebesar 2,6 yang berada pada kategori baik. Peningkatan rata-rata keterampilan proses sains peserta didik menandakan bahwa kekurangan atau kelemahan-kelemahan yang terdapat pada siklus I dapat teratasi sehingga keterampilan proses sains peserta didik dapat meningkat dari sebelumnya.

\section{Aktivitas Guru}

Aktivitas guru dalam mengelola pembelajaran juga mengalami peningkatan dari siklus I. Ada beberapa aspek aktivitas guru yang sebelumnya pada siklus I berada pada kategori cukup dan baik mengalami peningkatan pada siklus II sehingga berada pada kategori baik dan sangat baik. Hal ini pengelolaan pembelajaran yang dilakukan oleh guru telah sesuai dengan langkah-langkah model pembelajaran berbasis masalah, dimana skor rata-rata yang diperoleh sebesar 3,8 dengan kategori sangat baik.

\section{Hasil Belajar}

Meningkatnya keterampilan proses sains peserta didik dan aktivitas guru tersebut berdampak pada hasil belajar peserta didik. Berdasarkan hasil analisis deskriptif terhadap hasil belajar peserta didik pada 
siklus II untuk sub materi gejala gelombang (difraksi dan interferensi) mengalami peningkatan dari siklus I. Hal ini dapat dilihat pada Tabel 4.3, diperoleh nilai ratarata hasil belajar peserta didik sebesar 87,9, meskipun nilai maximum dan minimum yang diperoleh sama dengan siklus I. Jika diklasifikasikan nilai yang diperoleh peserta didik berada pada kategori tinggi hingga rendah.

Hal ini menunjukkan peningkatan persentase ketuntasan belajar peserta didik yang sebelumnya juga telah mencapai ketuntasan secara klasikal sebesar $86,2 \%$ dari jumlah peserta didik 29 orang, yang artinya telah mencapai bahkan melewati target penelitian sebesar 75\% ketuntasan secara klasikal. Dimana jumlah peserta didik yang tuntas sebanyak 25 orang dan yang tidak tuntas sebanyak 4 orang.

Peningkatan aktivitas guru, keterampilan proses sains dan hasil belajar peserta didik menunjukkan bahwa guru telah melakukan perbaikan berdasarkan analisis dan refleksi yang telah dilakukan sebelumnya. Ditinjau dari hasil belajar fisika yang diperoleh peserta didik untuk materi pokok gelombang mekanik pada tahun ajaran 2018/2019 lebih baik dibandingkan dengan hasil belajar yang diperoleh peserta didik tahun ajaran 2017/2018. Peningkatan tersebut sesuai dengan teori yang dijelaskan oleh Mulyasa (2006: 101) yang menyatakan bahwa suatu pembelajaran dapat dinyatakan berhasil dan berkualitas apabila seluruhnya atau setidak-tidaknya sebagian besar (75\%) siswa terlibat secara aktif, baik fisik, mental maupun sosial dalam proses pembelajaran.

Berdasarkan uraian di atas, dapat dikatakan bahwa penggunaan model pembelajaran berbasis masalah dengan berbantuan simulasi PhET di kelas XI MIA 3 SMAN 1 Mawasangka dapat meningkatkan keterampilan proses sains dan hasil belajar peserta didik pada materi pokok gelombang mekanik.

Sehingga dapat dikatakan penelitian ini sesuai dengan teori sebelumnya yaitu penelitian yang dilakukan oleh Jauhari, dkk (2016) bahwa model pembelajaran berbasis masalah berbantuan media PhET berpengaruh terhadap hasil belajar fisika peserta didik kelas $\mathrm{X}$ SMAN 1 Gunungsari tahun pelajaran 2015/2016. Model pembelajaran berbasis masalah berbantuan media PhET tersebut dapat dijadikan sebagai alternatif model pembelajaran yang dapat diterapkan untuk mengaktifkan peserta didik, sehingga hasil belajar peserta didik meningkat.

\section{KESIMPULAN}

Keterampilan proses sains peserta didik kelas XI MIA 3 SMAN 1 Mawasangka pada materi pokok gelombbang mekanik melalui penggunaan model pembelajaran berbasis masalah berbasis dengan berbantuan simulasi PhET mengalami peningkatan. Hal ini ditunjukkan dengan skor rata-rata aspek keterampilan Proses sains peserta didik pada siklus I dan siklus II. Dimana pada siklus I diperoleh skor mulai dari 1 sampai dengan 2,2 dengan skor rata-rata sebesar 1,9 yang berada pada kategori cukup. Selanjutnya pada siklus II diperoleh skor mulai dari 2,6 sampai dengan 3 dengan skor rata-rata sebesar 2,7 yang berada padaka tegori baik. Hasil belajar peserta didik kelas XI MIA 3 SMAN 1 Mawasangka yang diajar dengan menggunakan model pembelajaran berbasis masalah dengan berbantuan simulasi PhET pada materi pokok gelombang mekanik mengalami peningkatan hal ini menunjukkanpada siklus I diperoleh nilai mulai dari 60 sampai dengan 100 dengan skor rata-rata sebesar 86,0 pada siklus II diperoleh nilai mulai dari 60 sampai dengan 100 dengan skor rata-rata sebesar 87,9.

\section{DAFTAR PUSTAKA}

Arikunto, S. 2005. Manajemen Penelitian Edisi Revisi. Jakarta: Rineka Cipta.

Arsyad, A. 2014. Media Pembelajaran. Jakarta: Rajawali Press.

Borthick, F danJones, D.R. 2000. Motivation for Collaborative Online Learning Invention and Its Application in Information Systems Security Course. Issues in AccountingEducation. Vol.15 No. 2.

Damayanti, S. Q, Mahardika, I. K dan Indrawati. Penerapan Model Discovery Learning Berbantuan Media Animasi Macromedia Flash disertai LKS yang Terintegrasi dengan Multirepresentasi dalam Pembelajaran Fisika di SMA. Universitas Jember. Vol. 4 No. 4.

Hamiyah, N dan Jauhar, M. 2014. Strategi Belajar Mengajar di Kelas. Jakarta:Prestasi Pustaka.

Indagiarmi, Y dan Hakim, A. 2016. Pengaruh Model Pembelajaran Pembelajaran berbasis masalah Terhadap Hasil Belajar Peserta didik Kelas XI Semester II Pada Materi Pokok Fluida Dinamik di SMA. UNIMED. Vol. 5 No. 1.

Lidiana, H., Gunawan dan Taufik, M. 2018. Pengaruh Model Discovery Learning Bebantuan Media PhET terhadap Hasil Belajar Fisika Peserta Didik Kelas XI SMAN 1 Kediri Tahun Ajaran 2017/2018. Universitas Mataram. Vol. 4 No. 1. 
Komyadi dan Derlina. 2005Penerapan Media Simulasi PhET untuk Meningkatkan Aktivitas Peserta didik pada Fase Pengumpulan Data Percobaan dan Mengolah serta Merumuskan Suatu Penjelasan dalam Model Pembelajaran Inquiri Training di SMA Negeri 5 Takengon. Medan: Universitas Negeri Medan.

Noeraida. 2016. Modul Guru Pembelajar. Jakarta: Pusat Pengembangan dan Pemberdayaan Pendidik dan Tenaga Kependidikan Ilmu Pengetahuan Alam (PPPPTK IPA).

Nurkhayati,2003. Model Pembelajaran IPA dengan Starter Experimen Approach untuk meningkatkan keteampilan \& Pemahaman Konsep pada Murid Kelas V SD.Yogyakarta. Pemendikbud Nomor 81A Tahun 2013

Purwanto, N. 2010. Prinsip-prinsip dan Teknik Evaluasi Pengajaran. Bandung: PT Remaja Rosdakarya.

Purwanto, C.E, Nugroho, S.E, dan Wijayanto. 2012. Penerapan Model Pembelajaran Guided Discovery pada Materi Pemantulan Cahaya untuk Meningkatkan Berpikir Kritis. Semarang: Universitas Negeri Semarang.

Pujianto, Supardianingsih, dan Chasanah, R. 2016. Buku Peserta didik Fisika Untuk SMA/MA Kelas X. Klaten: Intan Pariwara.

Ramly. 2006. Evaluasi Pendidikan dan Penilaian Hasil Belajar. Kendari: Universitas Haluoleo.

Rustaman, A. 2005. Pengembangan Kompetensi (Pengetahuan, keterampilan, Sikap, dan Nilai) Melalui Kegiatan Praktikum Biologi. Penelitian Jurusan Pendidikan Biologi FPMIPA UPI Bandung.

Selcuk, G.S. 2010. The effects of problem-based lerning on pre-service teachers'achievement, approaches and attitudes towards lerning physics.International Journal of the Physial Sciences. Vol. 5 No. 6.

Septiani, L.R. 2014. Pengaruh Model Guided Discovery Terhadap Keterampilan Proses Sains dan Hasil Belajar IPA-Fisika Peserta didik Kelas VII SMP Negeri 1 Jelbuk. Jember: Universitas Jember.

Soetjipo, B.F. 2001. Inquirias Menthods of Implementating Active Learning. Jurnal Ilmu Pendidikan. Vol. 3 No.2. Malang: UniversistasNegeri Malang.

Sudijono, A. 1996. Pengantar dan Evaluasi Pendidikan. Jakarta: Raja Gravindo.

Sugiarti. 2015. Pembelajaran Fisika Berbantuan Simulasi PhET dalam Membangun Konsep
Peserta didik. Jurnal Ilmu Kependidikan. Vol. 13 No. 1.

Sudjana. 2002. Metoda Statistika (Edisi Revisi). Bandung: Tarsito.

Sudjana, N. 2010. Penelitian Hasil Proses Belajar Mengajar. Bandung: PT. Remaja Rosdakarya.

Usman, M dan Setiawati, L. 2001. Upaya Optimalisasi Kegiatan Belajar Mengajar. Bandung: PT. Remaja Rosdakarya.

Wicaksana, H dan Mardiyana., Usodo, B. 2016. Eksperimentasi Model Pembelajaran Problem Based Learning (PBL) dan Discovery Learning (DL) dengan Pendekatan Saintifik pada Materi Himpunan ditinjau dari Adversity Quotient (Aq) Peserta Didik. Surakarta: Universitas Sebelas Maret Surakarta.

Winataputra, U. S. 2007. Teori Belajar dan Pembelajaran. Jakarta:Universitas Terbuka.

Wuryaningsih, R dan Suharno. 2014. Penerapan Pembelajaran Fisika dengan Media Simulasi PhET Pada Pokok Bahasan Gaya untuk Meningkatkan Hasil Belajar Peserta didik Kelas VIII A SMPN 6 Yogyakarta. Yogyakarta: Universitas Ahmad Dahlan. 